\title{
Bioaccumulation of Trace Mercury in Trophic Levels of Benthic, Benthopelagic, Pelagic Fish Species, and Sea Birds from Arvand River, Iran
}

\author{
Mehdi Hosseini • Seyed Mohammad Bagher Nabavi • \\ Yaghob Parsa
}

Received: 7 July 2013 / Accepted: 2 October 2013 / Published online: 31 October 2013

(C) The Author(s) 2013. This article is published with open access at Springerlink.com

\begin{abstract}
In this study, concentration of mercury was determined in the trophic levels of benthic, benthopelagic, pelagic fish species, and river birds from Arvand River, located in the Khuzestan province in the lowlands of southwestern Iran at the head of the Persian Gulf. The order of mercury concentrations in tissues of the fish species was as follows: liver $>$ gill $>$ muscle and in tissues of the kingfisher species was as follows: feather $>$ liver $>$ kidney $>$ muscle. Therefore, liver in fish and feather in kingfisher exhibited higher mercury concentration than the other tissues. There was a positive correlation between mercury concentrations in fish and kingfisher species with size of its food items. We expected to see higher mercury levels in tissues of female species because they are larger and can eat larger food items. The results of this study show that the highest mean mercury level were found in the kingfisher (Anas crecca), followed by benthic (Epinephelus diacanthus), benthopelagic (Chanos chanos), and pelagic fish (Strongylura strongylura). Mean value of mercury in fish species, $S$. strongylura were $\left(0.61 \mu \mathrm{g} \mathrm{g}^{-1}\right.$ dry weight), $C$. chanos $\left(0.45 \mu \mathrm{g} \mathrm{g}^{-1}\right.$ dry weight), $E$. diacanthus $\left(0.87 \mathrm{\mu g} \mathrm{g}^{-1}\right.$ dry weight), and in kingfisher species A. crecca was $\left(2.64 \mu \mathrm{g} \mathrm{g}^{-1}\right.$ dry weight). Significant correlation between mercury concentration in fish and kingfisher may be related to high variability of mercury in the fish.
\end{abstract}

Keywords Mercury · Trophic levels · Fish · River birds · Arvand River

\footnotetext{
M. Hosseini $(\square)$

Department of Marine Biology, Faculty of Biological Science, Shahid Beheshti University, P.O. Box: 669, Tehran, Iran

e-mail: smhbio@yahoo.com

S. M. B. Nabavi • Y. Parsa

Department of Marine Biology, Faculty of Marine Science, Khoramshahr Marine Science and Technology University, Khoramshahr, Iran
}

\section{Introduction}

The Persian Gulf is a shallow and semi-enclosed sea that its environment is changing rapidly [1]. The discovery of oil in this sea led to a massive increase in anthropogenic activities in the area. For instance, this sea has about 800 offshore oil platforms and tolerates the traffic of about 25,000 oil tankers each year. The National Research Council in 1985 estimated that oil pollution in the Persian Gulf is $4.7 \%$ of the whole oil pollution in the world [2]. According to the results attained by ROPME, some areas of the sea are at a serious risk of metals pollution.

Mercury $(\mathrm{Hg})$ is one of the most hazardous environmental pollutants due to its toxicity and its accumulation in aquatic organisms. The relative toxicity of mercury depends on its chemical form, methyl mercury being one of the most toxic substances existing in the environment. The consumption of fish is the main route of exposure of humans to monomethylmercury, which represent the main form of mercury in fish due to biomagnification in the marine food chain $[3,4]$. Mercury exposure leads to numerous symptoms such as impaired vision and hearing, dizziness, vomiting, headache, muscular weakness, allergies, depressed immune system, brain damage, but finally can lead to death [5].

The toxic metal such as mercury that contaminates river, stream, and wetlands only accumulates in fish after it has been converted to the chemical compound methylmercury. Other forms of mercury do not magnify in concentration up the food chain. Methylmercury is created by bacteria in highly organic portions of aquatic systems, such as the sediment of river and wetlands. The zooplanktons pick up the methylmercury as they filter the water and feed on algae. When small fish eat zooplankton, the methylmercury builds up in their bodies as the fish grow bigger and older. Small fish are eaten by larger fish, and the concentration of methylmercury increases at each step in the aquatic food chain. It is highest in large walleye, 
northern pike, and other predatory fish [6]. It is the methylmercury in these fish that poses the greatest threat to human health. Fetuses, nursing infants, children under age 15, and people who rely on fish for much of their diet are most at risk from methylmercury, which can hamper normal development of the central nervous system. In adults, exposure to methylmercury can result in damage to the nervous system and organs [7].

It is known that certain forms of mercury can readily accumulate within organisms tissues at much higher levels than those in the water column and in sediment [8]. Mercury is a non-biodegradable contaminant that could enter aquatic food chains and consequently accumulates in organisms positioned in various trophic levels. Fish, which usually occupies the last levels of aquatic food chains, are considered as the main aquatic pathway for metals to be transferred into human body [9]. Biological and ecological factors such as ecological needs, habitat, and feeding habits [10] have significant influences on metals bioaccumulation, bioavailability, and therefore on their transference. However, feeding habit plays a significant role in the accumulation of pollutants in organism's tissues [9].

As birds are ordinarily at the top of the food web, they are valuable for environmental monitoring [11]. Fish-eating birds, as top level carnivores, often have high levels of contaminants [12]. Mercury accumulation in many piscivorous birds has been frequently reported [13-18], but determination of mercury in birds such as kingfishers is rare and less common [19-21]. However, since kingfishers have a wide range of distribution, are avid eaters (consuming more than $50 \%$ of their body weight each day), and obtain virtually all their food from aquatic systems [19], they make for excellent biomonitoring species.

The aims of this study were to determine the levels of mercury in the sediment, two species of fish and one species of kingfisher residing in Arvand River, Iran, and to determine the ability of each species and tissue in mercury accumulation.

\section{Material and Method}

\section{Study Area}

Sampling sites were selected along the Arvand River, northwest coasts of the Persian Gulf (Fig. 1). The Arvand River, the border between Iraq and Iran, is the biggest river in the Persian Gulf. It passes three main cities including Al-Basre in Iraq, Abadan and Khoramshahr in Iran. For people of these cities, the Arvand River is considered as a main resource of seafood and drinking water. This river is formed by the confluence of Shatt al-Arab in Iraq and Karoon River in Iran. In addition to receiving effluents of more than seven big and small Iranian and Iraqi cities, there are many non-pointed and pointed metals sources along its course [1]. This river is surrounded by many petrochemical units such as Abadan petrochemical complex and petroleum refinery. Also, metal concentration may be due to discharge of sewage and urban effluents and related to the oil tankers traffic in the river. In addition, the Arvand River carries about 48 t of oil residues to the northwest Persian Gulf annually $[1,2]$. Other sources of pollution in this area, including agricultural use of fertilizers, herbicides, pesticides, hazardous substance spills from various refineries, and wars and invasions, are yet to be methodically investigated [1].

\section{Collection Fish}

Three fish species (Epinephelus diacanthus, Chanos chanos, and Strongylura strongylura) were caught in July of 2011. The samples were placed on ice, immediately transported to the laboratory on the same day, and stored at $-20{ }^{\circ} \mathrm{C}$ until analysis [22].

For analysis, gill, muscle, and liver of each fish were dissected, freeze-dried, and crushed to uniform particle size [22]. It was then drained under folds of filter, weighed, wrapped in aluminum foil, and then frozen at $10{ }^{\circ} \mathrm{C}$ prior to analysis. The tissues were placed in clean watch glasses and were oven dried at $105{ }^{\circ} \mathrm{C}$ for $1 \mathrm{~h}$ and later cooled in the desiccators. Each sample of fish was homogenized in an acidcleaned mortar, and $2 \mathrm{~g}$ were digested in triplicate in a water bath at $60^{\circ} \mathrm{C}$ for $6 \mathrm{~h}$ after adding $2.5 \mathrm{~mL}$ each of concentrated $\mathrm{HNO}_{3}$ and $\mathrm{H}_{2} \mathrm{SO}_{4}$ [22].

\section{Collection Kingfisher}

The kingfisher Anas crecca was collected from Arvand River. These birds were collected from hunters who had shot them during October of 2011. The specimens were weighed, stored in polyethylene bags, and kept at $-20{ }^{\circ} \mathrm{C}$ until they were dissected and analyzed. Samples were thawed, and the liver, feather, muscle, and kidney were separately dissected from the bodies of the specimens. Samples were freeze-dried and homogenized $[16,23]$. Finally, they were changed into powder. Powdered sample and feather sample (finely cut) were directly weighed $(50-100 \pm 0.1 \mathrm{mg})$ into the precleaned combustion boats.

Each sample was analyzed for mercury by the mineralization method with $\mathrm{HNO}_{3}$ at $65 \%$, according to Basset et al. (1981) [22]. Analyses were optimized by hollow cathode lamps (LCO), according to the metallic element analyzed, and samples were read using a GBC-932 AA atomic absorption spectrophotometer [24]. The equipment was calibrated using metal stock solutions $(1,000 \mathrm{ppm})$. The recovery means for $\mathrm{Hg}$ was 112.4 and $102 \%$, respectively. 
Fig. 1 Map of Persian Gulf and study area (Arvand river)

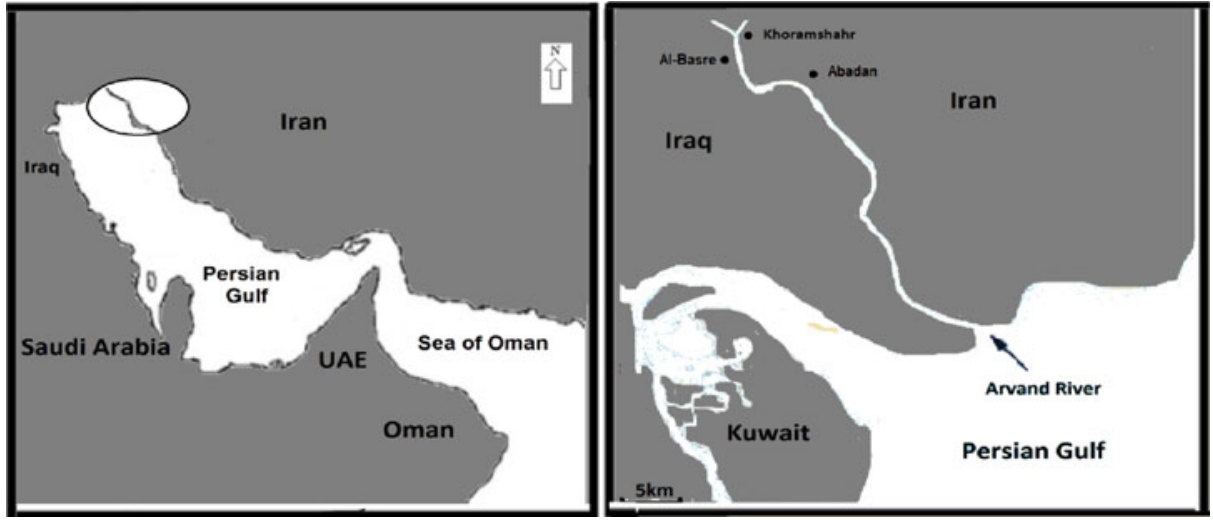

\section{Statistical Analysis}

The data were tested for normality using a Shapiro-Wilk test. The data were not normally distributed. Mercury concentrations in feather, livers, kidneys, and muscles were tested for mean differences among species using one-way analysis of variance fallowed by Duncan's post hoc test. All concentrations are reported in microgram per gram dry weight and a probability of $p=0.05$ was set to indicate statistical significance.

\section{Results and Discussion}

Table 1 shows the scientific name, feeding habitat, sex, and mean body weight for the species of fish samples. Mercury concentrations were calculated in microgram per gram wet basis ( $\mu \mathrm{g} \mathrm{g}^{-1}$ dry weight). In order to check the validity of the measurements, reference material (Multi-4, Merck) was used.

During the current study, mercury concentrations in tested tissues of all the fishes decreased in the order of liver $>$ gill $>$ muscle (Table 2). Metals are taken up by fishes from food and water, distributed throughout the fish body by blood, and eventually accumulated in target organs. Some tissues such as liver are considered as target organs for metals accumulation [25]. The very high levels of mercury in the liver for fish species in comparison to their muscle may be related to the content of metallothionein protein in liver tissue. Metallothionein protein that plays a significant role in the regulation and detoxification of mercury is produced in high levels in liver tissue [26]. This protein contains a high percentage of amino group, nitrogen and sulfur that sequester metals in stable complexes $[25,26]$. In general, the accumulation of mercury in the liver could have resulted from the abundance of metallothioneins proteins in these tissues in comparison to muscle. In this research, the comparison on metals accumulation between all tissues of fish show that bioaccumulation of metals was more in the liver than other tissues [27]. Some other researchers also reported that fish muscle generally contained the lowest amounts of these metals [2, 28, 29].

Gills usually reflect the concentrations of metals in surrounding water [10]. This organ is directly in contact with water and suspended materials, thus it could absorb different substances from the surrounding environment. They also serve a variety of physiological functions such as osmoregulation and gas exchange. Due to these functions, gills have remarkable influences on the exchange of toxic metals between a fish and its environment [30]. However, the muscle tended to accumulate less mercury in comparison to the liver and gills. This finding may reflect the low concentration of metallothioneins in the muscle tissue [10].

Table 1 Scientific name, feeding habitat, sex, and weight (Mean $\pm \mathrm{SE} g$ ) of the specimens

\begin{tabular}{|c|c|c|c|c|c|}
\hline Species & Scientific name & Feeding habitat & Sex & $n$ & Weight \\
\hline \multirow[t]{4}{*}{ Fish } & \multirow[t]{2}{*}{ Epinephelus diacanthus } & \multirow[t]{2}{*}{ Benthic predator: consumes mainly benthic invertebrates, detritus, and plant } & Females & 35 & $72 \pm 7.2$ \\
\hline & & & Males & 40 & $70 \pm 1.3$ \\
\hline & \multirow[t]{2}{*}{ Chanos chanos } & \multirow[t]{2}{*}{ Omnivorous: feeds on fish, shrimp, bivalvia, and crab } & Females & 36 & $80 \pm 1.8$ \\
\hline & & & Males & 32 & $73 \pm 2.4$ \\
\hline \multirow[t]{4}{*}{ Kingfisher } & \multirow[t]{2}{*}{ Strongylura strongylura } & \multirow[t]{2}{*}{ Fish predator: consumes mainly benthic fish } & Females & 42 & $89 \pm 4.9$ \\
\hline & & & Males & 39 & $82 \pm 1.4$ \\
\hline & \multirow[t]{2}{*}{ Anas crecca } & \multirow[t]{2}{*}{ Piscivorous: consumes mostly fish, also invertebrates and crustacean } & Females & 7 & $85 \pm 3.15$ \\
\hline & & & Males & 6 & $69 \pm 1.4$ \\
\hline
\end{tabular}


Table 2 Mercury concentration ( $\mu \mathrm{g} \mathrm{g}^{-1}$ dry weight) in tissues of three fish species and kingfisher species from Arvand river, northwest of the Persian Gulf

\begin{tabular}{lllllll}
\hline Species & & Liver & Gill & Muscle & Feather & Liver \\
\hline Strongylura strongylura & Mean \pm SE & $0.84 \pm 0.4$ & $0.58 \pm 0.6$ & $0.39 \pm 0.5$ & & \\
& Range & $0.11-1.37$ & $0.09-0.89$ & $0.05-0.71$ & \\
Chanos chanos & Mean \pm SE & $0.65 \pm 0.1$ & $0.43 \pm 0.3$ & $0.28 \pm 0.6$ & & \\
& Range & $0.11-1.07$ & $0.11-0.82$ & $0.11-0.83$ & & \\
Epinephelus diacanthus & Mean \pm SE & $1.2 \pm 0.4$ & $0.84 \pm 0.3$ & $0.58 \pm 0.7$ & & \\
& Range & $0.45-2.8$ & $0.28-2.1$ & $0.11-1.2$ & & $3.6 \pm 0.4$ \\
Anas crecca & Mean \pm SE & & & $1.1 \pm 0.6$ & $5.2 \pm 0.1$ & $1.6 \pm 0.2$ \\
& Range & & & $0.75-4.8$ & $1.3-8.6$ & $1.1-6.5$ \\
\hline
\end{tabular}

Mercury concentrations in tested tissues of the kingfisher decreased in the order of feather $>$ liver $>$ kidney $>$ muscle (Table 2). Mercury concentrations are usually found at the highest levels in feathers followed by liver, kidney, and muscle tissues [15, 20, 21]. In birds, feathers play a major role in mercury excretion [17]. Mercury accumulates especially well in bird feather because it has high affinity for the sulfhydryl groups in keratin [20,21].

Once metals enter a bird, they can be stored in internal tissues such as the kidneys and the liver [20, 21]. Many seabirds would demethylate organic $\mathrm{Hg}$ in tissues such as the liver and kidneys, and store a large portion of their $\mathrm{Hg}$ burdens in inorganic form [17]. Reports indicate that in a variety of wild caught birds, liver mercury levels are consistently higher than kidney levels which in turn exceed those in muscle $[11,15,16]$. This suggested markedly with studies which have reported levels of mercury in the kidney was higher than in the liver tissue [17-19, 31].

Lewis and Furness (1991) have reported mercury levels in the kidney that were most elevated in relation to the levels in the liver among black-headed gull (Larus ridibundus) which were given the highest dose of mercury. The ratio of levels in the kidney and liver may, therefore, be an indicator of mercury poisoning. Higher kidney to liver ratios may indicate elevated mercury levels [31].

The result also showed that there are differences in mercury concentration in the different species. The indicated variability of metal concentration in the different species depends on their habitats [26] and feeding habits and food sources [32].

In the present study, we considered two groups of fish including benthic species (E. diacanthus), benthopelagic ( $C$. chanos), and pelagic species ( $S$. strongylura) as candidate biological indicators for evaluating the effects of trophic levels and habitats on metal accumulation. E. diacanthus lives in close association with sediment and feeds mainly upon benthic organism, detritus, and tiny invertebrates. $C$. chanos is a benthopelagic species that feeds on pelagic species that feeds on shrimp, bivalvia, and crab. S. strongylura is a pelagic species that feeds on fish.
Also, we considered one species of kingfisher $A$. crecca that eat mainly fish and also aquatic crustacean and invertebrates.

Despite of being benthic and non-migratory fish, $E$. diacanthus indicated high mercury accumulation in their tissues. Because E. diacanthus feed on sediment and benthic organism and is close to bottom sediment and receive more sediment-associated mercury. Ratkowsky et al. (1975) studied mercury contamination of Derwent Estuary in Australia [33]. They found that there is a relationship between the frequency of high concentrations of mercury in fish tissues and feeding habits of the fish. According to Yi et al. (2008), heavy metal concentrations in food chain increase in the following order, benthic species followed by other species [25].

The concentration of mercury in the benthopelagic fish, $C$. chanos with respect to the other species may be related to crustaceans eating habits of the fish. The diet of C. chanos consists of crab, shrimp, and bivalvia. Crustaceans have been reported as a vector of the transfer of mercury element to top marine predators of the food chains [10].

The high concentration of mercury in the pelagic species, $S$. strongylura, may be related to fish eating habits of the species. The diet of S. strongylura consists of benthic fish. Mercury can readily accumulate within fish tissues at much higher levels and transfer to top predators that feed on them $[8,25]$.

The highest concentration of mercury was detected in tissues of kingfisher piscivorous $A$. crecca. Because organisms that are high on the trophic level might be expected to accumulate higher levels of bioaccumulative metals [10, 25]. Thus, in terms of mercury accumulation, the expected ranking in our study is kingfishers piscivorous $>$ benthic fish $>$ benthopelagic fish $>$ pelagic fish. Therefore, this finding could confirm that mercury concentration is heavily controlled by habitat and feeding habits $[10,34]$.

Since larger organisms generally exhibit higher contaminant level in their bodies $[10,28,34]$ and organisms that eat higher organisms also accumulate more contaminants when comparing to organisms that eat a range of different foods or eat smaller organisms. We expected to see higher mercury levels in tissues of female fishes because they are larger and 
can eat larger food items. In general, mercury levels have been shown to increase with size and age of the ingested fish, and it tends to be higher in species that occupy higher trophic levels [35]; based on this logic, we predicted that there should be higher levels of metals in the larger predators. Gewurtz et al. (2011) have shown that higher metal levels in female fish were due to the increased consumption of food [29].

Several studies indicate a difference in metal body burden between male and female birds [36, 37], while other studies report negligible differences in $\mathrm{Hg}$ between sexes [17-21]. We found that mercury values were larger in tissue of male species than the females (Fig. 2). This finding merits future investigation since a larger sample size will allow a more accurate analysis and detection of significant differences if they indeed exist. Other reports indicate that although female birds can get rid of $\mathrm{Hg}$ in their eggs, the amount they shed in this way is usually small compared to the amount placed into feathers during molt [36]. Therefore, the small difference that has been reported in $\mathrm{Hg}$ body burdens in male and female is consistent with our current data. Zamani et al. (2009) have shown that higher mercury levels were in female bird because they are larger and can eat larger food items [20,21].

Overall, these three species (fish and bird) feed at comparable trophic levels and exhibit similar foraging behavior. The fish species (residents of Arvand River) only have access to local food, but kingfisher $A$. crecca, which is migratory, can obtain food from other regions. We conclude that mercury concentrations in fish species reflect mercury contamination in Arvand River, but mercury burden of kingfisher $A$. crecca is a reflection of diversity in food items from wider geographical locations with perhaps much higher mercury pollution than the water of Iran and Iraq.

There was a significant correlation found between mercury concentrations in fish and bird tissues $(r=0.83, P<0.002$; Fig. 3). It is suggested that significant correlation between

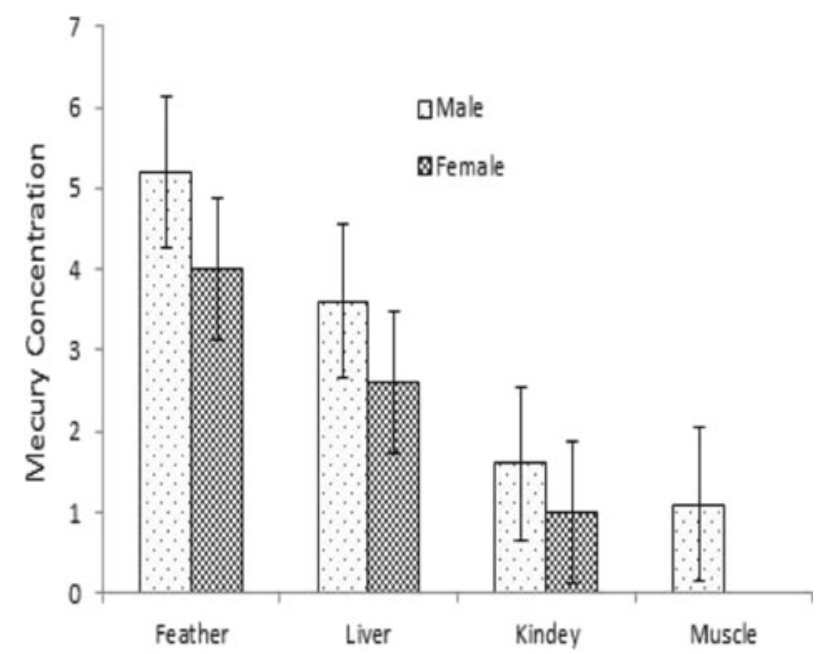

Fig. 2 Mercury concentration) $\mu \mathrm{g} \mathrm{g}^{-1}$ dry weight) in the tissues of male and female Anas crecca

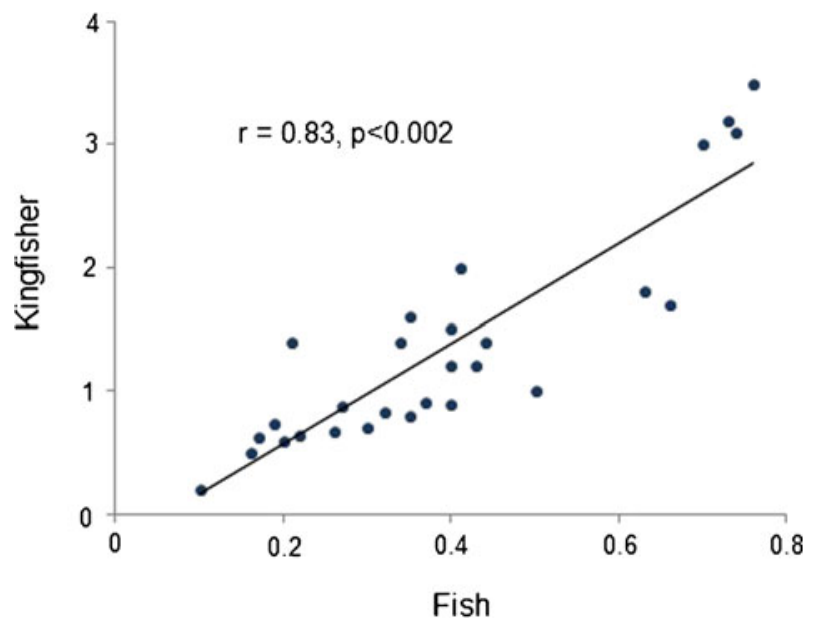

Fig. 3 Relationship of mercury concentrations $\left(\mu \mathrm{g} \mathrm{g}^{-1}\right)$ between fish and kingfisher

mercury concentration in fish and bird tissues may be related to high variability of mercury levels in the fish tissues. Therefore, this finding could be due to the differences in their ecological niches and feeding habitats. Therefore, A. crecca could be considered as suitable biomonitor agents for mercury contamination in the study area.

\section{Conclusion}

Our results indicated that the levels of mercury varied among species and tissues. Mercury can be transferred to higher trophic level by biomagnification. Also, mercury concentrations in high trophic level depend on the organisms of lowest trophic level. Therefore, the results of this study show that highest mean mercury level were found in the kingfisher $A$. crecca, followed by benthic fish, benthopelagic fish, and pelagic species. The results confirmed that the concentration of mercury in organisms strongly affected by habitat and feeding habit; however, the influences of habitat appears to be more than feeding habit. The fish species are traditional food for fishermen and traditional coastal communities, where it is an important source of protein. From a public health standpoint, measurement of mercury levels in the tissues of fishes is highly dangerous for human health. Therefore, studies of mercury concentrations in coastal areas are relevant and useful for monitoring the health of environmental compartments, maintenance of biodiversity, and for assuring the quality of life, mainly for humans. Finally, there is a need to develop and refine kingfisher model to serve as a sentinel of ecosystem health to help provide early warning indications for possible human exposure.

Acknowledgments The author would like to thank Dr. Hakim Jangali and Jabar Salamat for field assistance. This work was funded by the Environmental Protection of Tehran, Iran. A special thanks to all colleagues that helped during field work. 
Open Access This article is distributed under the terms of the Creative Commons Attribution License which permits any use, distribution, and reproduction in any medium, provided the original author(s) and the source are credited.

\section{References}

1. Sheppard C, Al-Husiani M, Al-Jamali F, Al-Yamani F, Baldwin R, Bishop J, Benzoni F, Dutrieux E, Dulvy NK, Durvasula SRV, Jones DA, Loughland R, Medio D, Nithyanandan M, Pillingm GM, Polikarpov I, Price ARG, Purkis S, Riegl B, Saburova M, Samimi Namin K, Taylor O, Wilson S, Zainal Z (2010) The gulf: a young sea in decline. Mar Pollut Bull 60:13-38

2. Al-Saleh I, Shinwari N (2002) Preliminary report on the levels of elements in four fish species from the Arabian Gulf of Saudi Arabia. Chemosphere 48:749-755

3. Barbosa AC, de Souza J, Dorea JG, Jardim WF, Fadini PS (2003) Mercury biomagnification in a Tropical Black Water, Rio Negro, Brazil. Arch Environ Contam Toxicol 45:235-246

4. Cheng Z, Liang P, Shao D-D, Wu S-C, Nie X-P, Chen K-C, Li K-B, Wong M-H (2011) Mercury biomagnification in the aquaculture pond ecosystem in the Pearl River Delta. Arch Environ Contam Toxicol 61:491-499

5. Risher JF (2003) Elemental mercury and inorganic mercury compounds: human health aspects. World Health Organization, Geneva

6. Fitzgerald WF, Lamborg CH, Hammerschmidt CR (2007) Marine biogeochemical cycling of mercury. Chem Rev 107:641-662

7. Pirrone N, Costa P, Pacyna JM, Ferrara R (2001) Mercury emissions to the atmosphere from natural and anthropogenic sources in the Mediterranean region. Atmos Environ 35:2997-3006

8. Beltrame MO, Marco SGD (2010) Influences of sex, habitat, and seasonality on heavy-metal concentrations in the burrowing crab (Neohelice granulate) from a coastal lagoon in Argentina. Arch Environ Contam Toxicol 58:746-756

9. Svensson BG, Schutz A, Nilsson A, Akesson I, Akesson B, Skerfving S (1992) Fish as a source of exposure to mercury and selenium. Sci Total Environ 126:61-74

10. Bustamante P, Bocher P, Cherel Y, Miramand P, Caurant F (2003) Distribution of trace elements in the tissues of benthic and pelagic fish from the Kerguelen Islands. Sci Total Environ 313:25-39

11. Horai S, Watanabe I, Takada H, Iwamizu Y, Hayashi T, Tanabe S, Kuno K (2007) Trace element accumulations in 13 avian species collected from the Kanto area, Japan. Sci Total Environ 373:512-525

12. Burger J, Gochfeld M (1991) Lead, mercury, and cadmium in feathers of tropical terns in Puerto Rico and Australia. Arch Environ Contam Toxicol 21:311-315

13. Thompson DR, Furness RW (1989) The chemical form of mercury stored in South Atlantic seabirds. Environ Pollut 60:305-317

14. Monteiro LR, Granadeiro JP, Furness RW, Oliveira P (1999) Contemporary patterns of mercury contamination in the Portuguese Atlantic inferred from mercury concentrations in seabird tissues. Mar Environ Res 47:137-156

15. Kim EY, Murakami T, Saeki K, Tatsukawa R (1996) Mercury levels and its chemical form in tissues and organs of seabirds. Arch Environ Contam Toxicol 30:259-266

16. Houserova P, Kuban V, Kracmar S, Sitko J (2007) Total mercury and mercury species in birds and fish in an aquatic ecosystem in the Czech Republic. Environ Pollut 145:185-194

17. Saeki K, Okabe Y, Kim EY, Tanabe S, Fukuda M, Tatsukawa R (2000) Mercury and cadmium in common cormorants (Phalacrocorax carbo). Environ Pollut 108:249-255
18. Nam DH, Anan YI, Kemoto T, Okabe Y, Kim EY, Subramanian A, Saeki K, Tanabe S (2005) Specific accumulation of 20 trace elements in great cormorants (Phalacrocorax carbo) from Japan. Environ Pollut 134:503-514

19. Baron LA, Ashwood TL, Sample BE, Welsh C (1997) Monitoring bioaccumulation of contaminants in the belted kingfisher (Ceryle alcyon). Environ Monit Assess 47:153-165

20. Al-Hello AA, Al-Obaidy AM (1997) The chemistry of Shatt Al-Arab water from Qurna to Al-Fao. Mar Mesopotamica 12:190-201

21. Zamani-Ahmadmahmoodi R, Esmaili-Sari A, Ghasempoury SM, Savabieasfahani M (2008) Mercury levels in selected tissues of three kingfisher species; Ceryle rudis, Alcedo atthis, and Halcyon smyrnensi, from Shadegan Marshes of Iran. Ecotoxicology 18:319-324

22. Basset J, Denney RC, Jeffery GH, Mendhan J (1981) Vogel: Analise Inorganica Quantitativa, fourthed. Guanabara S. A, Rio de Janeiro

23. Ruelas-Inzunza J, Paez-Osuna F (2004) Trace metals in tissues of resident and migratory birds from a lagoon associated with an agricultural drainage basin (SE Gulf of California). Arch Environ Contam Toxicol 47:117-125

24. Athanasopoulos N (1993) Flame methods manual for atomic absorption. GBC Scientific Equipment PTY Ltd, Victoria

25. YI Y, Wang Z, Zhang K, Yu G, Duan X (2008) Sediment pollution and its effect on fish through food chain in the Yangtze River. Int $\mathrm{J}$ Sediment Res 23:338-347

26. Yilmaz AB, Y1lmaz L (2007) Influences of sex and seasons on levels of heavy metals in tissues of green tiger shrimp (Penaeus semisulcatus de Hann, 1844). Food Chem 101:1664-1669

27. Pourang N, Nikouyan A, Dennis JH (2005) Trace element concentrations in fish, surficial sediments and water from northern part of the Persian Gulf. Environ Monit Assess 109:293-316

28. Abdolahpur Monikh F, Safahieh AR, Savari A, Doraghi A (2012) Heavy metal concentration in sediment, benthic, benthopelagic, and pelagic fish species from Musa Estuary (Persian Gulf). Environ Monit Assess. doi:10.1007/s10661-012-2545-9

29. Gewurtz SB, Bhavsar SP, Fletcher R (2011) Influence of fish size and sex on mercury/PCB concentration: importance for fish consumption advisories. Environ Int 37:425-434

30. Farkas A, Salanki J, Specziar A (2003) Age and size-specific patterns of heavy metals in the organs of freshwater fish Abramis brama L. populating a low-contaminated site. Water Res 37:959-964

31. Lewis SA, Furness RW (1991) Mercury accumulation and excretion in laboratory reared black-headed gull Larus ridibundus chicks. Arch Environ Contam Toxicol 21:316-320

32. Caussy D, Gochfeld M, Gurzau E, Neagu C, Ruedel H (2003) Lessons from case studies of metals: investigating exposure, bioavailability, and risk. Ecotoxicol Environ Saf 56:45-51

33. Ratkowsky DA, Dix TG, Wilson KC (1975) Mercury in fish in the Derwent Estuary, Tasmania, and its relation to the position of the fish in the food chain. Aust J Mar Freshwat Res 26: 223-231

34. Agah H, Leermakers M, Elskens M, Fatemi SMR, Baeyens W (2009) Accumulation of trace metals in the muscle and liver tissues of five fish species from the Persian Gulf. Environ Monit Assess 157:499-514

35. Phillips GR, Lenhart TE, Gregory RW (1980) Relation between trophic position and mercury accumulation among fishes from the Tongue River reservoir. Environ Res 22:73-80

36. Furness RW (1993) Birds as monitors of pollutants. In: Furness RW, Greenwood JJD (eds) Birds as monitors of environmental change. Chapman \& Hall, London, p 103

37. Gochfeld M, Burger J (1987) Heavy metal concentrations in the liver of three duck species: influence of species and sex. Environ Pollut Ser A $45: 1-15$ 